\author{
О.К. Шейгас, М.П. Долина, С.Ю. Вусатий, Т.В. Іванова, Ю.В. Мевша
}

Харківський національний університет Повітряних Сил ім. І. Кожедуба, Харків

\title{
ЗАПОБІГАННЯ ЗІТКНЕННЯ ПАРАШУТИСТІВ 3 БОЙОВОЮ ТЕХНІКОЮ НА ДІЛЯНЦІ ЗНИЖЕННЯ
}

Ефективність і безпека виконання задач одночасного десантування повітряного десанту та бойової техніки суттєво залежить від рівня фахової підготовки та надійної роботи екіпажів транспортної авіації i керівника десантування на майданчику приземлення. Актуальним є питання аналізу та оцінки параметрів визначення безпечних інтервалу відстані між літаками в обраному бойовому порядку, суворого витримування в ньому місия, щзо виключить зіткнення парашутистів з бойовою технікою на ділянці зниження. На підставі изього доцільно обгрунтувати методичні рекомендації посадовим особам штурманської служби щзодо запобігання зіткнення парашутистів з бойовою технікою.

Ключові слова: десантування парашутним способом,довжина серії парашутистів (бойової техніки), середнє квадратичне відхилення, графоаналітичне моделювання, балістична характеристика повільно падаючого тіла.

\section{Вступ}

Постановка проблеми. Одним із першочергових завдань застосування транспортної авіації за призначенням була та залишаться проблема підвищення безпеки польотів, зменшення авіаційних подій, заподіяних з вини членів екіпажу та керівника десантування на майданчику приземлення [1].

Безпека повітряного десантування потребує постійної кропіткої роботи усіх посадових осіб і направлена, перш за все, на бездоганне виконання ними вимог керівних документів, що визначають порядок організації та виконання польотів на десантування парашутним способом [1-2].

Основна частина польотів на парашутне десантування виконується в складних метеорологічних умовах, в складі груп при мінімальних дистанціях між літаками, а також на майданчики, розташовані в обмеженому районі [3].

Виходячи з відзначеного, актуальним є питання аналізу та оцінки параметрів визначення безпечних інтервалу відстані між літаками в обраному бойовому порядку, суворого витримування в ньому місця, що виключить зіткнення парашутистів з бойовою технікою на ділянці зниження. На підставі цього доцільно обгрунтувати методичні рекомендації посадовим особам штурманської служби щодо запобігання зіткнення парашутистів з бойовою технікою.

Аналіз літератури. В роботах [3-11] розглянуто особливості балістики повільно падаючих тіл (ППТ), положення теорії парашутного десантування щодо принципу вирішення завдань прицілювання за допомогою прицільно-навігаційного комплексу, рекомендації льотному складу та керівникам десантування на майданчиках приземлення щодо запобі- гання десантування військ, військової техніки та вантажів за межами заданих майданчиків приземлення, методику оцінки штурманом авіаційного підрозділу параметрів району та майданчиків приземлення. Разом з тим, у відомих роботах не висвітлені питання забезпечення безпеки одночасного десантування парашутним способом повітряного десанту та бойової техніки стосовно мінімальних безпечних дистанцій між літаками в бойових порядках, обрання раціонального виду (форми) бойового порядку, розрахунку часу витримки покидання літака бойовим розрахунком.

Мета статті. Аналіз вихідних даних для оцінки безпечних відстаней між групами літаків, які десантують особовий склад і бойову техніку, та розрахунок часових дистанцій між літаками (ведучими загонів, пар) при одночасному десантуванні бойової техніки та особового складу, надання пропозицій особам штурманської служби щодо запобігання зіткнення парашутистів з бойовою технікою на ділянці зниження.

\section{Виклад основного матеріалу}

Для запобігання зіткнення парашутистів з бойовою технікою на ділянці зниження можна використовувати кілька способів.

Перший спосіб полягає в призначенні для парашутистів і бойової техніки, що скидаються з різних літаків, окремих ділянок приземлення в межах меж майданчика, що пов'язано з визначенням і двох ТПВ десанту. Залежно від розмірів майданчика ділянки приземлення можна рознести як по фронту, так і по глибині. Мінімально допустима відстань між ділянками приземлення по фронту майданчика повинна бути не менше 
$I_{\min } \geq 4,23 \sigma_{T \Pi B}+l \sin \Delta \gamma^{\prime}+i+\Delta T_{3 H} U_{\text {бок }}$,

де $\sigma_{T П в}$-середньоквадратичне відхилення помилки виходу в ТНВ по напрямку (точність десантування);

$l$ - довжина серії парашутистів (бойової техніки);

$\Delta \gamma$ - допустима помилка в напрямку виходу в THB;

i - ширина бойового порядку;

$\Delta T_{3 H}-$ різниця в часі зниження парашутистів (бойової техніки, вантажів), що викидаються на сусідні по фронту майданчика;

$U_{\text {бок }}$ - бічна складова середнього вітру.

Однак навіть при незначному рознесенні ділянок приземлення потрібен майданчик великих розмірів по ширині, що не завжди можливо. Так, при $\sigma_{T \Pi B}=325 \mu, \quad \sigma_{T \Pi B}=0^{\circ}, \quad i=400 \mu, \Delta T_{3 H}=20 c$, $U_{\text {бок }}=10$ м / п потрібна ширина майданчика приземлення повинна бути збільшена на 2000 м [5]. Крім того, цей метод можна застосовувати в разі, коли одна група літаків виконує десантування тільки парашутистів, а інша - тільки бойової техніки.

Мінімально допустима відстань між ділянками приземлення по глибині майданчика повинна бути не менше

$$
S_{\min } \geq l+S_{\text {без }},
$$

де $l$ - довжина серії парашутистів (бойової техніки), які скидаються на початку майданчика;

$$
S_{\text {без }}=V_{\partial e c}\left(\Delta t_{5 \Pi_{r}}+\Delta t_{5 \Pi_{A_{a b}}}+\Delta t_{5 \Pi_{U}}+\Delta t_{Б \Pi_{l}}\right)-
$$

безпечна відстань між кінцем серії бойової техніки (парашутистів) і початком серії парашутистів (бойової техніки);

$\Delta t_{Б \Pi_{r}}$ - складова тимчасової дистанції, що враховує помилки виходу в ТНВ по дальності (точність десантування по дальності);

$$
\Delta t_{Б \Pi_{A_{a в}}} \text { - складова тимчасової дистанції, що }
$$
враховує аварійні випадки зниження платформ (зниження на витяжному або стабілізуючому парашуті);

$\Delta t_{Б \Pi_{U}}-$ складова тимчасової дистанції, що враховує вплив вітру (поздовжня складова);

$\Delta t_{Б \Pi_{l}}$ - складова тимчасової дистанції, що враховує помилки у визначенні довжини серії парашутистів (бойової техніки).

Розрахунки, виконані за формулою (2), показують, що для роздільного скидання бойової техніки і особового складу з літаків Іл-76МД (бойова техніка приземляється на початку майданчика) мінімально допустима відстань між ділянками приземлення має бути не менше 3400 м [6]. А якщо врахувати, що для приземлення особового складу треба ділянку довжиною 1850 м (десантування $з$ літака Іл-76МД 115 чоловік в 4 потоки), потреба у виборі майданчика великих розмірів стає очевидною. Тому на практиці перший спосіб не знаходить широкого застосування [5-6].

Другий спосіб полягає в призначенні безпечної дистанції між групою літаків, які десантують особовий склад, і групою літаків, які десантують бойову техніку, при якій виключається небезпека зіткнення їх на траєкторії зниження.

Це забезпечується в тому випадку, коли до моменту викидання бойової техніки, що залишився, зниження парашутистів виявиться не більше загального часу зниження бойової техніки, тобто за умови, що

$$
\begin{aligned}
& \Delta t_{\text {БП }} \geq t_{\text {зн.n }}-t_{\text {зн.бт }}+t_{c е р}+3 \sigma_{c е р}+3 \sigma t_{M Л Н}+ \\
& +4,23 \sigma t_{\Delta H}+4,23 \sigma t_{r}+\Delta t_{\text {БП }},
\end{aligned}
$$

де $t_{\text {зн.n }}, t_{\text {зн.бт }}$ - час зниження парашутистів і бойової техніки (від моменту натискання на кнопку скидання) відповідно;

$t_{c e p}$ - довжина серії парашутистів за часом;

$\sigma t_{M Л Н}$ - середньоквадратичне відхилення помилки виміру дальності витримування місця в бойовому порядку за допомогою системи МЛН;

$\sigma t_{\Delta H}$ - середньоквадратичне відхилення помилки через похибки вимірювання і витримування висоти десантування;

$\sigma t_{r}$ - середньоквадратичне відхилення помилки виходу в ТНВ за місцем (точність десантування).

Результати розрахунків, виконаних за формулою (3), наведені в табл. 1. У розрахунках прийнято значення $U=10$ м $/ c, K K B=180^{\circ}$.

\begin{tabular}{|c|c|c|c|c|c|c|c|c|}
\hline \multirow{2}{*}{ 氙密 } & \multicolumn{8}{|c|}{ Висота десантування, м } \\
\hline & ) & \& & $\begin{array}{l}8 \\
i\end{array}$ & 8 & 8 & రి & ஓ & ᄋ̊ \\
\hline 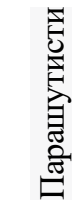 & $\tilde{y}$ & $\sqrt{6}$ & 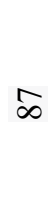 & $\hat{0}$ & $\widehat{\beth}$ & 守 & $\underline{6}$ & $\infty$ \\
\hline$\sum_{\text {主 }}$ & ' & 1 & $\stackrel{n}{2}$ & ñ & $\infty$ & ষ & $\stackrel{n}{n}$ & $i n$ \\
\hline 立 & ' & I & 疋 & 6 & $\stackrel{\infty}{\sim}$ & $\infty$ & $\underset{0}{0}$ & $\stackrel{\cong}{=}$ \\
\hline$\frac{0}{\square}$ & 1 & 1 & ' & ' & ' & ' & ă & 으 \\
\hline
\end{tabular}

Вихідні дані, які використовуються для розрахунку, наведені в табл. 2.

Таблиця 1

Час зниження парашутистів (БТ) $t_{\text {зн }}, \mathrm{c}$ 
Безпечна дистанція між групами літаків, які десантують о/с і бойову техніку $\Delta t_{Б П}, \mathrm{~m}$

\begin{tabular}{|c|c|c|c|c|c|c|c|}
\hline \multirow{3}{*}{$\frac{\sum_{b}^{E}}{\stackrel{5}{s}}$} & $\sum_{\text {具 }}$ & 6 & $\stackrel{2}{2}$ & 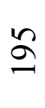 & $\bar{\nabla}$ & 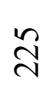 & $\stackrel{0}{\sim}$ \\
\hline & 吉 & $\tilde{n}$ & $\stackrel{\text { I }}{ \pm}$ & $\bar{n}$ & $\bar{\sigma}$ & 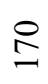 & 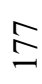 \\
\hline & $\begin{array}{l}0 \\
\stackrel{1}{二}\end{array}$ & ' & ' & ' & ' & 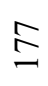 & $\infty$ \\
\hline
\end{tabular}

Таблиця 2

Вихідні дані, які використовуються для розрахунку

\begin{tabular}{|c|c|}
\hline Параметр & Іл-76МД \\
\hline$t_{c e p}, \mathrm{c}$ & 36 \\
\hline$\sigma t_{c e p}, \mathrm{c}$ & 3,17 \\
\hline$\sigma t_{M 3 H}, \mathrm{c}$ & 8 \\
\hline$\sigma t_{\Delta H}, \mathrm{c}$ & 2,28 \\
\hline$\sigma t_{r}, \mathrm{c}$ & 3,85 \\
\hline$V_{\text {дес }}$, км/год & 300 \\
\hline
\end{tabular}

Аналіз даних, наведених в табл. 1, показує, що тимчасова дистанція між групами повинна становити 2-3 хв при десантуванні платформ П-7 і 3-4 хв при десантуванні ПРСМ. 3 метою максимального скорочення глибини бойового порядку з'єднань в момент викидання десанту і виключення можливості зіткнення парашутистів 3 бойовою технікою на траєкторії зниження, бойові порядки доцільно будувати так, щоб групи літаків з парашутами слідували за групою літаків з бойовою технікою.

У разі коли проводиться одночасне десантування бойової техніки і особового складу розрахунків 3 кожного літака групи, для запобігання їх зіткнення на етапі зниження тимчасова дистанція між літаками (провідними загонами, пар) повинна бути не менше мінімально допустимої [9]. На підставі графоаналітичного моделювання траєкторії зниження парашутистів і бойової техніки при викиданні їх 3 бойових порядків величина цієї дистанції може бути розрахована за формулою

$$
\begin{aligned}
& t_{\text {БП }} t_{3 н . n}-t_{\text {зн.бт }}+\Delta t_{Б \Pi_{A_{0}}}+3 \sigma t_{M 3 H}+4,23 \sigma t_{r}+ \\
& +4,23 \sigma t_{\Delta H}+\Delta t_{5 \Pi_{U}}+\Delta t_{5 \Pi_{A_{a b}}},
\end{aligned}
$$

де $\Delta t_{Б \Pi_{U}}$ - складова тимчасової дистанції, що враховує впливання вітру;

$\Delta t_{Б \Pi_{A_{a b}}}$ - складова тимчасової дистанції, що враховує аварійні випадки зниження платформ тіль- ки на витяжному парашуті;

$\Delta t_{Б \Pi_{A_{0}}}$ - складова тимчасової дистанції, що враховує балістичні характеристики МПТ.

Складова тимчасової дистанції, що враховує вплив вітру, розраховується за формулою

$$
\Delta t_{Б \Pi_{U}}=\frac{\left(t_{3 н . б m}-t_{3 н . \Pi}\right)}{W_{\partial е c}} \cos \mathrm{KKB} .
$$

Результати розрахунків, виконаних за формулою (5), приведені в табл. 3.

Складова тимчасової дистанції, що враховує аварійні зниження платформ тільки на витяжному парашуті, розраховується за формулою

$$
\Delta t_{5 \Pi_{A_{a b}}}=\frac{A_{0}-A_{0_{a \beta}}}{V_{\partial e c}},
$$

де: $A_{0}$ - штильове віднесення платформи;

$A_{0_{a в}}-$ віднесенні платформи в аварійному випадку.

Результати розрахунків, виконаних за формулою (6), наведені в табл. 4.

\begin{tabular}{|c|c|c|c|c|c|c|c|}
\hline \multirow{3}{*}{ 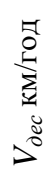 } & \multirow{3}{*}{$\begin{array}{l}\frac{0}{\Sigma} \\
D\end{array}$} & \multicolumn{6}{|c|}{ ПРСМ } \\
\hline & & \multicolumn{6}{|c|}{$H_{\partial e c}=500 \mathrm{M}$} \\
\hline & & 0 & 45 & & & 135 & 180 \\
\hline \multirow{5}{*}{$\underset{m}{8}$} & 2 & -1 & -1 & & & 1 & 2 \\
\hline & 4 & -3 & -2 & & & 2 & 3 \\
\hline & 6 & -4 & -3 & & & 4 & 5 \\
\hline & 8 & -5 & -4 & & & 5 & 6 \\
\hline & 10 & -7 & -5 & & & 6 & 8 \\
\hline \multirow{5}{*}{ in } & 2 & -1 & -1 & & & 1 & 2 \\
\hline & 4 & -2 & -1 & & & 2 & 3 \\
\hline & 6 & -3 & -2 & & & 3 & 4 \\
\hline & 8 & -5 & -3 & & & 4 & 6 \\
\hline & 10 & -6 & -4 & & & 5 & 7 \\
\hline \multirow{5}{*}{$\underset{n}{\stackrel{R}{n}}$} & 2 & -1 & 0 & & & 1 & 2 \\
\hline & 4 & -2 & -1 & & & 2 & 3 \\
\hline & 6 & -3 & -2 & & & 3 & 4 \\
\hline & 8 & -4 & -3 & & & 4 & 5 \\
\hline & 10 & -6 & -4 & & & 5 & 7 \\
\hline 공 & 0 & \multicolumn{6}{|c|}{ ПРСМ } \\
\hline $\begin{array}{l}\sum \\
8 \\
8\end{array}$ & $\begin{array}{l}\Sigma \\
D^{\prime}\end{array}$ & \multicolumn{6}{|c|}{$H_{\partial e c}=800 \mathrm{M}$} \\
\hline 0 & & 0 & & 15 & 90 & 135 & 180 \\
\hline \multirow{5}{*}{ \&ి } & 2 & -1 & & 1 & 0 & 1 & 2 \\
\hline & 4 & -3 & & -2 & 0 & 2 & 3 \\
\hline & 6 & -4 & & 3 & 0 & 4 & 5 \\
\hline & 8 & -5 & & -4 & 0 & 5 & 6 \\
\hline & 10 & -7 & & 5 & 0 & 6 & 8 \\
\hline
\end{tabular}

Таблиця 3

Складова тимчасової дистанції, $\Delta t_{Б \Pi_{U}}$ с, включаючи вплив вітру, в залежності від ККВ, градуси 
Закінчення табл. 3

\begin{tabular}{|c|c|c|c|c|c|c|}
\hline \multirow{4}{*}{$\approx$} & 2 & -1 & -1 & 0 & 1 & 2 \\
\cline { 2 - 7 } & 4 & -2 & -1 & 0 & 2 & 3 \\
\cline { 2 - 7 } & 6 & -3 & -2 & 0 & 3 & 4 \\
\cline { 2 - 7 } & 8 & -5 & -3 & 0 & 4 & 6 \\
\cline { 2 - 7 } & 10 & -6 & -4 & 0 & 5 & 7 \\
\hline \multirow{4}{*}{$\underset{m}{\infty}$} & 2 & -1 & 0 & 0 & 1 & 2 \\
\cline { 2 - 7 } & 4 & -2 & -1 & 0 & 2 & 3 \\
\cline { 2 - 7 } & 6 & -3 & -2 & 0 & 3 & 4 \\
\cline { 2 - 7 } & 8 & -4 & -3 & 0 & 4 & 5 \\
\cline { 2 - 7 } & 10 & -6 & -4 & 0 & 5 & 7 \\
\hline
\end{tabular}

\begin{tabular}{|c|c|c|c|c|c|c|}
\hline \multirow{3}{*}{ 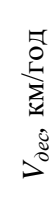 } & \multirow{3}{*}{$\begin{array}{l}0 \\
\Sigma \\
\Delta\end{array}$} & \multicolumn{5}{|c|}{ П-7 } \\
\hline & & \multicolumn{5}{|c|}{$H_{\partial e c}=500 \mathrm{M}$} \\
\hline & & 0 & 45 & 90 & 135 & 180 \\
\hline \multirow{5}{*}{$\underset{ల}{8}$} & 2 & 0 & 0 & 0 & 1 & 1 \\
\hline & 4 & -1 & -1 & 0 & 2 & 2 \\
\hline & 6 & -2 & -1 & 0 & 2 & 3 \\
\hline & 8 & -3 & -2 & 0 & 3 & 4 \\
\hline & 10 & -4 & -2 & 0 & 3 & 5 \\
\hline \multirow{5}{*}{ in } & 2 & -1 & 0 & 0 & 1 & 2 \\
\hline & 4 & -1 & 0 & 0 & 1 & 2 \\
\hline & 6 & -2 & -1 & 0 & 2 & 3 \\
\hline & 8 & -2 & -2 & 0 & 2 & 3 \\
\hline & 10 & -3 & -2 & 0 & 3 & 4 \\
\hline \multirow{3}{*}{ 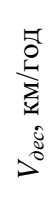 } & \multirow{3}{*}{$\begin{array}{l}0 \\
\bar{z} \\
\vdots \\
D\end{array}$} & \multicolumn{5}{|c|}{ П-7 } \\
\hline & & \multicolumn{5}{|c|}{$H_{\partial e c}=800 \mathrm{M}$} \\
\hline & & 0 & 45 & 90 & 135 & 180 \\
\hline \multirow{5}{*}{ \&్ల } & 2 & 0 & 0 & 0 & 1 & 1 \\
\hline & 4 & -1 & -1 & 0 & 2 & 2 \\
\hline & 6 & -2 & -1 & 0 & 2 & 3 \\
\hline & 8 & -3 & -2 & 0 & 3 & 4 \\
\hline & 10 & -4 & -2 & 0 & 3 & 5 \\
\hline \multirow{5}{*}{ in } & 2 & -1 & 0 & 0 & 1 & 2 \\
\hline & 4 & -1 & 0 & 0 & 1 & 2 \\
\hline & 6 & -2 & -1 & 0 & 2 & 3 \\
\hline & 8 & -2 & -2 & 0 & 2 & 3 \\
\hline & 10 & -3 & -2 & 0 & 3 & 4 \\
\hline
\end{tabular}

Таблиця 4

Складова часової дистанції $\Delta t_{Б \Pi_{A_{a \varepsilon}}}, \mathrm{c}$, в залежності від $H_{\partial е c}$, м

\begin{tabular}{|c|c|c|c|c|c|}
\hline \multirow{2}{*}{ 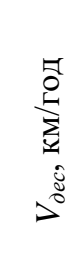 } & \multicolumn{2}{|c|}{ ПРСМ } & \multicolumn{2}{|c|}{ П-7 } & П-16 \\
\hline & 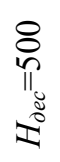 & 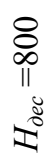 & 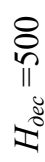 & $\begin{array}{l}8 \\
\pi_{0} \\
\stackrel{\Xi}{2}\end{array}$ & $\frac{8}{8}$ \\
\hline 260 & 5 & 6 & 6 & 7 & - \\
\hline 300 & 5 & 6 & 6 & 7 & 8 \\
\hline 350 & 6 & 7 & 7 & 8 & 8 \\
\hline 370 & 6 & 7 & 7 & 8 & 8 \\
\hline
\end{tabular}

Складова тимчасової дистанції, що враховує балістичні характеристики МПТ, розраховується за формулою

$$
\Delta t_{Б \Pi_{A_{0}}}=\frac{A_{0_{B T}}-A_{0_{n}}}{V_{\text {dec }}},
$$

де $A_{0_{Б}}$ - штильовий відніс платформи;

$A_{0_{n}}$ - штильовий відніс парашутиста;

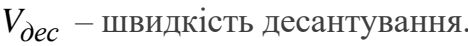

Результати розрахунків, виконаних за формулою (7), наведені в табл. 5.

Таблиця 5

Складова часової дистанції $\Delta t_{Б \Pi_{A_{0}}}, \mathrm{c}$, в залежності від $H_{\text {дес }}$, м

\begin{tabular}{|c|c|c|c|c|c|}
\hline \multirow{2}{*}{ 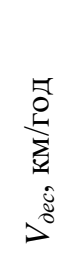 } & \multicolumn{2}{|c|}{ ПРСМ } & \multicolumn{2}{|c|}{ П-7 } & П-16 \\
\hline & 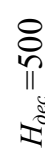 & 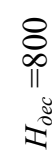 & 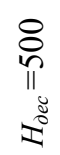 & 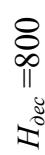 & $\frac{8}{\pi_{\mathscr{J}}}$ \\
\hline 260 & 5 & 5 & 6 & 6 & - \\
\hline 300 & 5 & 5 & 6 & 6 & - \\
\hline 350 & 4 & 4 & 5 & 5 & - \\
\hline 370 & 4 & 4 & 5 & 5 & 8 \\
\hline
\end{tabular}

Результати розрахунків, виконаних за формулою (4), наведені в табл. 6.

Аналіз даних, наведених в табл. 6, показує, що при одночасному десантуванні 3 кожного літака бойової техніки i особового складу розрахунків тимчасова дистанція між літаками (ведучих загонів, пар) повинна становити величину не менше:

- 2,5-3 хв при десантуванні ПРСМ 3 літаків Іл-76МД;

- 2-2,5 хв при десантуванні П-7 3 літака Іл-76МД

- 2,5-3 хв при десантуванні П-16.

Таблиця 6

Тимчасова дистанція між літаками (провідними загонів, пар) $\Delta t_{Б П ~}, \mathrm{c}$, при одночасному десантуванні бойової техніки і особового складу розрахунків

\begin{tabular}{|c|c|c|c|}
\hline \multirow{4}{*}{$\begin{array}{c}\text { Тип } \\
\text { платформи }\end{array}$} & $H_{\text {деc }}=500 \mathrm{M}$ & $H_{\text {деc }}=800 \mathrm{M}$ & $H_{\text {деc }}=1000 \mathrm{M}$ \\
\cline { 2 - 3 } & $V_{n p}=300$ & $V_{n p}=300$ & \\
\cline { 2 - 3 } & $V_{n}=350$ & $V_{n p}=350$ & \multirow{2}{*}{$V_{n p}=370$} \\
\cline { 2 - 3 } & $V_{n p}=370$ & $V_{n p}=370$ & \\
\hline
\end{tabular}


Закінчення табл. 6

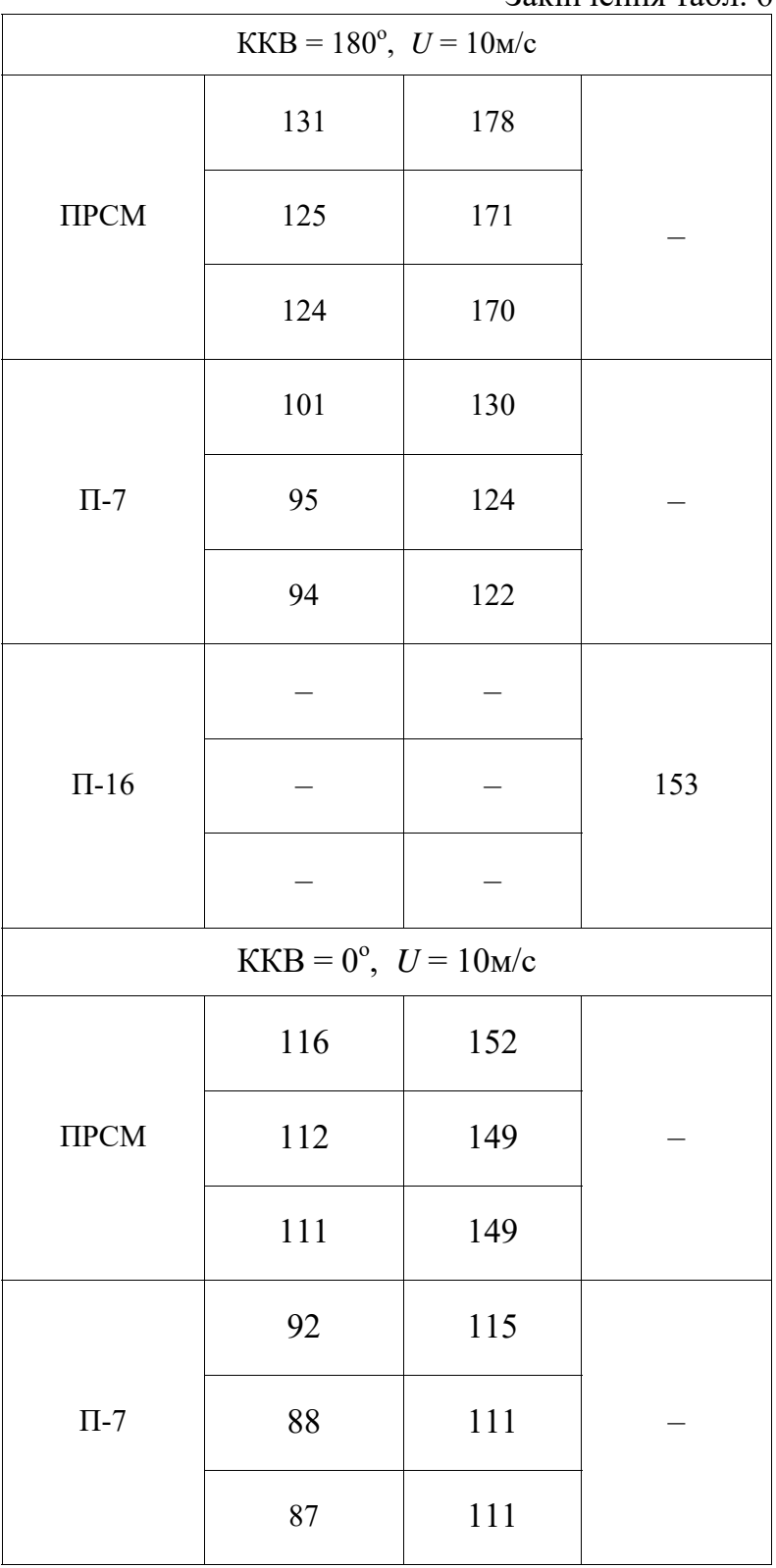

Скорочення дистанції між літаками бойового порядку можна досягти підвищенням точності витримування заданої дистанції і висоти, підвищенням точності десантування і ступеня безвідмовної роботи основних куполів платформ, а також зменшенням висоти десантування. Так, при зменшенні висоти десантування з 800 м (десантування платформ П-7 і бойової обслуги) до висоти 500 м тимчасова дистанція зменшується на 23-24\% і становить величину $\Delta t_{\text {БП }}=101 c$ (з літаків Іл-76МД).

3 метою скорочення глибини бойового порядку з'єднань десантування доцільно виконувати з бойового порядку “потік загонів” (“потік пар”, “змійка пар”) на тимчасовій дистанції між ведучими загонами (пар) не менше мінімально допустимої, розрахованої за формулою. Виняток зіткнення бойового розрахунку з бойовою технікою досягається при цьому вибором виду змійки літаків в загоні (пеленга пари).

Як показують результати графоаналітичного моделювання, вид змійки літаків в загоні (вид пеленга пари) залежить від напрямку середнього вітру.

При наявності бічного вітру перший ведений в загоні (ведений в парі) повинен знаходитися з вітряного боку.

При зустрічному, попутному вітрі і в штиль вид змійки в загоні (вид пеленга в парі) не впливає на безпеку десантування і буде визначатися рішенням командира.

Запобігання зіткнення бойового розрахунку 3 бойовою технікою на етапі зниження можна досягти розміщенням його в бойових машинах десанту і на платформах, дистанція між літаками в бойовому порядку буде визначатися в цьому випадку вимогами запобігання зіткнення літаків між собою при маневруванні і прицілюванні.

Запобігання зіткнення бойового розрахунку 3 бойовою технікою на етапі зниження при одночасному їх десантуванні з одного літака можна досягти, крім того, десантуванням бойової техніки і розрахунків в різні райони одного майданчика приземлення. Для цього бойовий розрахунок повинен покинути літак за останньою платформою через час витримки $\left(t_{\text {вид }}\right)$, що дорівнює

$$
t_{\text {вид }}=\Delta t_{Б \Pi_{A_{0}}}+\Delta t_{Б \Pi_{U}}+\Delta t_{Б \Pi_{A_{a \beta}}}+\Delta t_{Б \Pi_{r}},
$$

3 аналізу результатів видно, що при десантуванні платформи П-7 і бойової обслуги з літака Іл76МД час витримки складає 22-25 с при попутному вітрі $(U=10 \mathrm{M} / \mathrm{c})$ і $33-38 \mathrm{c}-$ при зустрічному вітрі.

Роздільне приземлення бойової техніки і розрахунків дозволяє скоротити тимчасову дистанцію між літаками на величину, рівну часу витримки, що становить 27-33\%, однак це вимагає наявності великих майданчиків приземлення.

Потрібна довжина площадки в даному випадку визначається за такою залежністю:

$$
L_{\text {потр }}=B_{\text {од }}+l_{\text {бm }}+l_{n}+S_{\text {без }},
$$

де $B_{о д}$ - потрібна довжина площадки для одиночного десантування;

$l_{б m}$ - лінійна величина серії бойової техніки;

$l_{n}$ - лінійна величина серії бойового розрахунку;

$S_{\text {без }}$ - безпечна відстань між кінцем серії бойової техніки і початком серії бойової обслуги.

Розрахунки, виконані за формулою, показують, що для виконання десантування 3 літака Іл-76МД трьох платформ П-7 і бойового розрахунку в складі 17 чоловік з висоти $800 \mathrm{м} \quad\left(V_{д е с}=300 \kappa м /\right.$ год, $E=200 \mu, \quad P=0,95)$ потрібна довжина площадки складатиме величину $L_{n o m p}=5257$ м . 


\section{Висновки}

Запобігання зіткнення парашутистів 3 бойовою технікою на ділянці зниження можна досягти скороченням дистанції між літаками бойового порядку за рахунок підвищення точності витримування заданої дистанції і висоти, підвищенням точності десантування і ступеня безвідмовної роботи основних куполів платформ, а також зменшенням висоти десантування.

3 метою скорочення глибини бойового порядку з'єднань десантування доцільно виконувати з бойового порядку “потік загонів” (“потік пар”, “змійка пар”) на тимчасовій дистанції між ведучими загонами (пар) не менше мінімально допустимої.

Як показують результати графоаналітичного моделювання, вид змійки літаків в загоні (вид пеленга пари) залежить від напрямку середнього вітру.
При наявності бічного вітру перший ведений в загоні (ведений в парі) повинен знаходитися з вітряного боку. При зустрічному, попутному вітрі і в штиль вид змійки в загоні (вид пеленга в парі) не впливає на безпеку десантування і буде визначатися рішенням командира.

Запобігання зіткнення бойового розрахунку 3 бойовою технікою на етапі зниження можна досягти розміщенням його в бойових машинах десанту і на платформах, дистанція між літаками в бойовому порядку буде визначатися в цьому випадку вимогами запобігання зіткнення літаків між собою при маневруванні і прицілюванні. Запобігання зіткнення бойового розрахунку з бойовою технікою на етапі зниження при одночасному їх десантуванні з одного літака можна досягти, крім того, десантуванням бойової техніки і розрахунків в різні райони одного майданчика приземлення.

\section{Список літератури}

1. Правила штурманського забезпечення польотів державної авіації України (ПШЗПДАУ-2016). - Вінниця: МО України, 2016. - 104 с.

2. Правила виконання польотів державної авіації України (ПВПДАУ-2015). - Вінниця: МО України, 2015. - 227 с.

3. Забезпечення безпеки десантування повітряного десанту в обмеженому районі / О.К. Шейгас, А.І. Пономаренко, П.Д. Шуртаков, Д.О. Букшань // Збірник наукових праць ХНУПС. - 2018. -№ 3(57). - С. 32-37. https://doi.org/10.30748/zhups.2018.57.05.

4. Кибардин Ю.А. Иследование спутного аеродинамического следа военных самолетов на безопасность полетов / Ю.А. Кибардин, Л.М. Алпеев. - Ворошиловград: ВВВАУШ, 1987. - 96 с.

5. Коваленко Н.П. Прицельный навигационно-пилотажный комплекс и его применение в целях самолетовождения / Н.П. Коваленко,В.И. Ефременко, Н.А. Поляков. - Ворошиловград: ВВВАУШ, 1985. - 220 с.

6. Малеткин В.Н. Применение ПНПК в целях десантирования / В.Н. Малеткин, Л.М. Алпеев. - Ворошиловград: ВВВАУШ, 1990. - $91 \mathrm{c.}$

7. Самолетовождение и бомбометание / под. ред. В.Д. Тимофеева. - М. : Воениздат, 1979. - 480 с.

8. Корочкін О.А. Теорія парашутного десантування / О.А. Корочкін, А.П. Корнієнко, Е.А. Скуба. - Харків: ХУПС, 2011. $-156 \mathrm{c}$.

9. Шейгас О.К. Формалізація процесу вирішення задачі визначення напрямків удару засобів повітряного нападу на оперативному напрямку / О.К. Шейгас // Системи обробки інформації. - Харків: ХУПС, 2014. - Вип. 5(121) - С. 120-125.

10. Алімпієв А.М. Особливості гібридної війни РФ проти України. Досвід, що отриманий Повітряними Силами Збройних Сил України / А.М. Алімпієв, Г.В. Пєвцов // Наука і техніка Повітряних Сил Збройних Сил України. - 2017. № 2(27). - C. 19-25. https://doi.org/10.30748/nitps.2017.27.03.

11. Онипченко П.М. Напрямки підвищення оперативності і якості бойової підготовки льотного складу авіації Повітряних Сил Збройних Сил України / П.М. Онипченко, М.А. Павленко, О.І. Тимочко // Системи обробки інформації. Харків: ХУПС, 2016. - № 3(140). - С. 264-266.

12. Онипченко П.Н. Управление воздушным движением и перспективные направления его совершенствования / П.Н. Онипченко, М.А. Павленко, А.И. Тимочко // Наука і техніка Повітряних Сил Збройних Сил України. - 2015. № 2(19). - С. 38-41.

13. Герасимов С.В. Методи обробки вихідних сигналів динамічних систем при визначенні їх технічного стану/ С.В. Герасимов, О. І. Тимочко // Системи обробки інформації. - 2014. - № 6(122). - С. 31-35.

14. Методика оцінки штурманом авіаційного підрозділу параметрів району та майданчиків приземлення / О.К. Шейгас, В.П. Приймак, О.О. Сухінін, А.А. Шликов // Збірник наукових праць ХНУПС. - 2017. - № 5(54). - С. 75-79.

\section{References}

1. Ministry of Defense of Ukraine (2016), "Pravyla shturmanskoho zabezpechennia polotiv derzhavnoi aviatsii Ukrainy (PJSCFAU-2016)" [Rules of navigational support for flights of the State Aviation of Ukraine (PJSCFAU-2016)], Vinnytsya, $104 \mathrm{p}$.

2. Ministry of Defense of Ukraine (2015), "Pravyla vykonannia polotiv derzhavnoi aviatsii Ukrainy (PVPDAU-2015)" [The rules of carrying out flights of state aviation of Ukraine (PVPDAU-2015)], Vinnitsa, $227 \mathrm{p}$.

3. Sheigas, O.K., Ponomarenko, A.I., Shurtakov, P.D. and Bukshan, D.O. (2018), "Zabezpechennia bezpeky desantuvannia povitrianoho desantu v obmezhenomu raioni" [Providing safety of air dropping of paratoops inlimited region], Scientific Works of Kharkiv National Air Force University, No. 3(57), pp. 32-37. https://doi.org/10.30748/zhups.2018.57.05. 
4. Kibardin, Y.A. and Alpiev, L.M. (1987), "Ysledovanye sputnoho aerodynamycheskoho sleda voennikh samoletov na bezopasnost poletov" [Investigation of the wake-up aerodynamic trail of military aircraft for flight safety], VVVAUSh, Voroshilovgrad, $96 \mathrm{p}$.

5. Kovalenko, N.P., Efremenko, V.I. and Polyakov, N.A. (1985), "Prytselnii navyhatsyonno-pylotazhnii kompleks y ehoprymenenye $v$ tseliakh samoletovozhdenyia" [Sighting navigation and airborne complex and its application for the purpose of airplane production], VVVAVUSH, Voroshilovgrad, $220 \mathrm{p}$.

6. Maletkin, V.N. and Alpeev, L.M. (1990), "Prymenenye PNPK v tseliakh desantyrovanyia" [Application of PNPK for the purpose of landing], VVVAUSH, Voroshilovgrad, $91 \mathrm{p}$.

7. Timofeev, V.D. (1979), "Samoletovozhdenye y bombometanye" [Aircraft and bombing], Voenizdat, Moscow, 480 p.

8. Korochkin, O.A., Kornienko, A.P. and Scuba, E.A. (2011), "Teoriia parashutnoho desantuvannia" [The theory of parachute landing], KAFU, Kharkiv, $156 \mathrm{p}$.

9. Shaigas, O.K. (2014), "Formalizatsiia protsesu vyrishennia zadachi vyznachennia napriamkiv udaru zasobiv povitrianoho napadu na operatyvnomu napriamku" [Formalization of the process of solving the problem of determining the direction of impact of airborne attack on the operational direction], Information Processing Systems, No. 5(121), pp. 120-125.

10. Alimpiev, A.M. and Pevtsov, G.V. (2017), "Osoblyvosti hibrydnoi viiny RF proty Ukrainy. Dosvid, shcho otrymanyi Povitrianymy Sylamy Zbroinykh Syl Ukrainy" [Features of the hybrid war against the Russian Federation. Experience gained by the Air Forces of the Armed Forces of Ukraine], Science and Technology of the Air Force of Ukraine, No. 2(27), pp. 19-25. https://doi.org/10.30748/nitps.2017.27.03.

11. Onipchenko, P.M., Pavlenko, M.A. and Tymochko, O.I. (2016), "Napriamky pidvyshchennia operatyvnosti i yakosti boiovoi pidhotovky lotnoho skladu aviatsii Povitrianykh Syl Zbroinykh Syl Ukrainy" [Directions of increasing the efficiency and quality of combat training of the Air Forces of the Armed Forces of Ukraine], Information Processing Systems, No. 3(140), pp. 264-266.

12. Onipchenko, P.M., Pavlenko, M.A. and Tymochko, O.I. (2015), "Upravlenye vozdushnim dvyzhenyem y perspektyvne napravlenyia eho sovershenstvovanyia" [Management of air traffic and perspective directions of its perfection], Science and Technology of the Air Force of Ukraine, No. 2(19), pp. 38-41.

13. Gerasimov, S.V. and Timochko, O.I. (2014), "Metody obrobky vykhidnykh syhnaliv dynamichnykh system pry vyznachenni yikh tekhnichnoho stanu" [Methods of processing output signals of dynamic systems in determining their technical state], Information Processing Systems, No. 6(122), pp. 31-35.

14. Shaigas, O.K., Priyamak, V.P., Sukhinin, O.O. and Shlikov, A.A. (2017), "Metodyka otsinky shturmanom aviatsiinoho pidrozdilu parametriv raionu ta maidanchykiv pryzemlennia" [Method of estimation by the navigator of the aviation unit of the parameters of the area and landing sites], Scientific Works of Kharkiv National Air Force University, No. 5(54), pp. 75-79.

\section{Відомості про авторів:}

\author{
Шейгас Олександр Костянтинович \\ кандидат технічних наук доцент \\ начальник кафедри Харківського національного \\ університету Повітряних Сил ім. І. Кожедуба, \\ Харків, Україна \\ https://orcid.org/0000-0001-8172-4948
}

\section{Долина Михайло Петрович}

кандидат військових наук доцент старший науковий співробітник

Харківського національного університету

Повітряних Сил ім. І. Кожедуба,

Харків, Україна

https://orcid.org/0000-0002-0872-4033

\section{Вусатий Сергій Юрійович}

магістрант

Харківського національного університету

Повітряних Сил ім. І. Кожедуба,

Харків, Україна

https://orcid.org/0000-0002-7661-037X
Information about the authors:

\section{Oleksandr Shaigas}

Candidate of Technical Sciences Associate Professor

Head of Department of Ivan Kozhedub

Kharkiv National Air Force University,

Kharkiv, Ukraine

https://orcid.org/0000-0001-8172-4948

\section{Mihailo Dolina}

Candidate of Military Sciences Associate Professor

Senior Research Associate

of Ivan Kozhedub Kharkiv

National Air Force University,

Kharkiv, Ukraine

https://orcid.org/0000-0002-0872-4033

\section{Serhii Vusatyi}

Postgraduate Student

of Ivan Kozhedub

Kharkiv National Air Force University,

Kharkiv, Ukraine

https://orcid.org/0000-0002-7661-037X 
Іванова Тетяна Василівна

магістрант

Харківського національного університету

Повітряних Сил ім. І. Кожедуба,

Харків, Україна

https://orcid.org/0000-0001-6455-38-41

\section{Мевша Юлія Вячеславівна}

магістрант

Харківського національного університету

Повітряних Сил ім. І. Кожедуба,

Харків, Україна

https://orcid.org/0000-0002-6699-1586
Tetiana Ivanova

Postgraduate Student

of Ivan Kozhedub

Kharkiv National Air Force University,

Kharkiv, Ukraine

https://orcid.org/0000-0001-6455-3841

Yuliia Mevsha

Postgraduate Student

of Ivan Kozhedub

Kharkiv National Air Force University,

Kharkiv, Ukraine

https://orcid.org/0000-0002-6699-1586

\title{
ПРЕДОТВРАЩЕНИЕ СТОЛКНОВЕНИЯ ПАРАШЮТИСТОВ С БОЕВОЙ ТЕХНИКОЙ НА УЧАСТКЕ СНИЖЕНИЯ
}

\author{
А.К. Шейгас, М.П. Долина, С.Ю. Вусатий, Т.В. Иванова, Ю.В. Мевша
}

Эффективность и безопасность выполнения задач одновременного десантирования воздушного десанта и боевой техники существенно зависит от уровня профессиональной подготовки и надежной работы экипажей транспортной авиации и руководителя десантирования на площуаке приземления. Актуален вопрос анализа и оценки параметров определения безопасных интервалов расстояния между самолетами в выбранном боевом порядке, строгое выдерживания в нем места, которое исключит столкновения парашютистов с боевой техникой на участке снижения. На основании этого ичелесообразно обосновать методические рекомендации должностным лицам итурманской службы на счет предотвращения столкновения парашютистов с боевой техникой.

Ключевые слова: десантирование парашютным способом, длинна серии парашютистов (боевой техники), среднее квадратическое отклонение, графоаналитическое отклонение, графоаналитическое моделирование, баллистическая характеристика медленно падающего тела.

\section{THE PREVENTION OF COLLISIONS PARATROOPS WITH COMBAT TECHNIQUE ON PHASE OF LANDING}

\section{O. Sheygas, M. Dolina, S. Vusatyi, T. Ivanova, Yu. Mevsha}

Efficiency and security of simultaneous airborne insertion of paratroops and combat technique heavily depends on the level of professional preparation and reliable cooperation inside cabin crew of cargo aviation and the head of air-assault on the landing site. The relevant question is about analysis and assessment parameters of identifying safety spacing between aircraft in chosen combat order, strictly maintenance of a fixed place that excludes the collision paratroops with combat techniques in phase of landing. Basing on this, should be an appropriate to justify the methodic recommendation to officials of navigation services about prevention of collisions paratroops with combat technique. Analyzed original data for assessment safety distance between groups of aircraft that are performing air-assaulting troops, combat techniques and evaluated time interval between aircraft while simultaneous airdropping combat techniques and personnel. Reduction of a distance between aircraft of combat order could be increase by accuracy of maintaining fixed distance and altitude, increasing accuracy of airdropping and the level of fail-free operation of main dome of a platform. Shown results of graphic analytic modeling show us the type of snake aircraft, in order that depends on direction of wind. Prevention of collision combat evaluations with combat techniques on phase of landing could be achieve by employment in airborne fighting vehicle and platforms, distance between aircraft in combat order will be determine in this case by requirements of prevention collision of aircraft between each other. Prevention the collision of combat evaluations with combat techniques on phase of landing by simultaneous airdropping from one aircraft could be achieved airdropping combat techniques and evaluations in different regions of one place of landing.

Keywords: para dropping, long of line paratroops (combat techniques), average quadratic deviation, graphic and analytic modeling, ballistic characteristic slow body drop. 